\title{
Urgences
}

\section{Bertrand B. Leblanc, Variations sur un thème anathème, Montréal, Leméac, 1983.}

\section{Clément Lévesque}

Numéro 10, 2e trimestre 1984

\section{Spécial fantasmes}

URI : https://id.erudit.org/iderudit/025165ar

DOI : https://doi.org/10.7202/025165ar

Aller au sommaire du numéro

\section{Éditeur(s)}

Urgences

\section{ISSN}

0226-9554 (imprimé)

1927-3924 (numérique)

Découvrir la revue

Citer ce compte rendu

Lévesque, C. (1984). Compte rendu de [Bertrand B. Leblanc, Variations sur un thème anathème, Montréal, Leméac, 1983.] Urgences, (10), 125-127.

https://doi.org/10.7202/025165ar d'utilisation que vous pouvez consulter en ligne.

https://apropos.erudit.org/fr/usagers/politique-dutilisation/ 
VARIATIONS SUR UN THÈME ANATHĖME, de Bertrand B. Leblanc, Leméac, 1983.

Dès le départ, une mise en garde: ne pas se fier à la couverture style Playboy, ni à l'éditeur qui promet des contes érotiques. C'est une alléchante table des matières... et une fausse piste.

Dans les onze Variations sur un thème anathème, on cherche en vain une atmosphère baignée de sensualité ou de longues descriptions lascives. La sexualité y est verdeur de langage et prétexte à des récits où Leblanc, le conteur, brosse un tableau de moeurs d'une certaine Gaspésie.

Des personnages "au bel accent chantant de la Gaspésie des Acadiens" (p. 130), amoureux d'une mer qui leur tourne le dos, attirée par des chalutiers hauturiers, vivent avec truculence, et néanmoins moult échecs, leur sexualité sur la terre ferme, comme si la mer, maîtresse infidèle, était seule gage d'amour heureux.

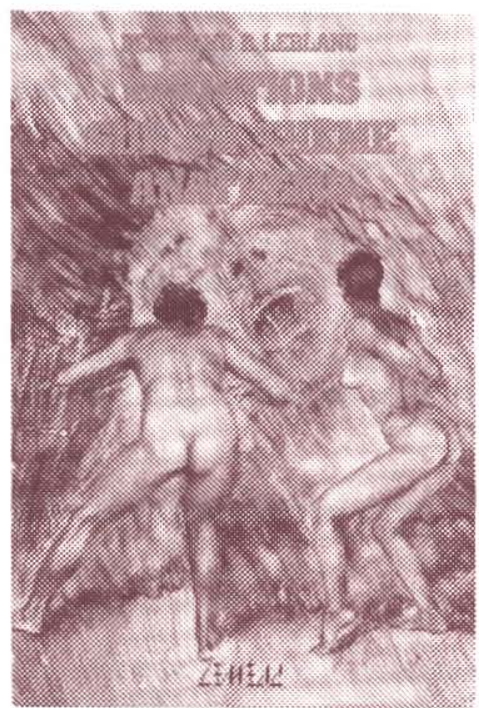


De l'oncle Arcade ("Le Pertuis"), cultivateur et vieux garçon, on dira qu'un "Gaspésien qui préfère la terre à la mer, et en apparence sans regret, ne mérite pas mieux" (p. 49) que le célibat. Son mariage tardif à la belle Zénoïde, une fillette de 15 ans, malgré un bonheur apparent, cache une déception profonde.

Pour avoir renié la mer en construisant une piscine sur sa propriété, le docteur Allard ("La Piscine") découvre que sa femme le trompe avec "tante" Margot.

Sam, l'idiot du village, n'a jamais "été en mer, ce qui était inadmissible" (p. 144) ("Le Banc d'oeuvre"). "Un homme digne de ce nom veut bien obéir aux saisons, aux lunes et aux marées mais se précipiter au sifflet d'une usine, obtempérer aux hurlements d'un contremaître, non! C'était un esclavage inadmissible pour un pêcheur" (p. 140)..

Le récit "Le Boutefeu" illustre avec le plus de justesse la tragédie de ces Gaspésiens floués. Aurèle Bastarache, ancien pêcheur recyclé dynamiteur, "maudissait un métier qui ne permettait des vacances qu'en hiver" (p. 35). Pour "endurer huit mois d'enfer" (p. 35) annuel, il s'enferme seul, des semaines complètes, dans son sous-sol et, dans son délire éthylique, se prend pour "le Surcouf de la Gaspésie" (p. 32), lui qui tremble de mécontenter son contremaître.

Mais si le destin des personnages des Variations est tragique, le ton des récits est léger, spontané, joyeux et... sans recherche. Sur des canevas peu élaborés, Leblanc, à grands traits, dessine des personnages qui cachent mal leur tragédie intime sous l'exubérance du langage et d'une sexualité débridée.

Trop souvent, nous avons l'impression que l'auteur se fie

* Surcouf, Robert (1778-1827). Navigateur français et pirate qui sillonna l'océan Indien capturant de nombreux navires anglais. Dictionnaire Robert 2. 
à son talent et se laisse emporter par les mots et les jeux de mots. Une image en amène une autre, une grivoiserie en suggère d'autres, si bien que le récit s'épivarde. D'ailleurs le "thème anathème" est rarement bien intégré au récit. L'Eros, ou plutôt la verdeur du langage à propos du sexe, dénature fréquemmert le texte au point de lui faire perdre toute crédibilité. Ainsi, "Le Boutefeu" expurgé de quelques pages salées ferait mieux ressortir la tragédie d'Aurèle Bastarache sans enlever au conte ni sa légèreté, ni son impact.

En fermant le livre, le lecteur garde l'impression d'une oeuvre trop rapidement écrite. L'auteur s'y amuse beaucoup sans réussir à nous faire partager son extase.

Pour connaître le "vrai" Leblanc, plein de verve, au verbe coloré, portant un regard amusé sur le monde, il vaudrait mieux lire $\mathrm{Y}$ sont fous le grand monde! ou assister à la pièce de théâtre, Faut divorcer!. C'est du vrai Leblanc!

Clément Lévesque 